\title{
Effect of CIDR 12 to 19 Days After Al on Detection of Returning Estrus and Conception Rate in Dairy Cows
}

\author{
Su T. LONG ${ }^{1)}$, Toshihiko NAKAO'), Shuichi WAKATAKE') and Masaaki OKAKOI ${ }^{3)}$ \\ ${ }^{1)}$ Laboratory of Theriogenology, Department of Veterinary Medicine, Faculty of Agriculture, Yamaguchi University, \\ Yamaguchi 753-8515, ${ }^{2)}$ Wakatake Veterinary Clinic, Tottori 682-0721 and ${ }^{3)}$ Ishikari NOSAl, Hokkaido 067-0055, Japan
}

\begin{abstract}
Detection of returning estrus in dairy cows after AI and re-insemination without delay are important in shortening the calving to conception interval. The objectives of this study were to show the effectiveness of CIDR insertion 12 to 19 days after AI on returning estrus and shortening the calving to conception interval in dairy cows. Seventy-nine dairy cows from two commercial dairy farms were synchronized for first postpartum estrus using a CIDRHeatsynch protocol, and 76 cows (96.2\%) showed estrus signs within 2 days after EB injection and were inseminated. The cows were then divided randomly into two groups. Thirty-seven cows were treated with a CIDR from 12 to 19 days after AI (CIDR group), while the other 39 cows were not treated and served as a control group. Milk samples were collected twice weekly from one week before the commencement of the CIDR-Heatsynch protocol until 7 to 9 days after removal of device. Detection rates of returning estrus 20 to 25 days after AI (within 6 days after removal of the device) were $30.4 \%$ in the CIDR group and $47.6 \%$ in the control group. According to the progesterone profiles, almost half of the non-pregnant cows that did not show estrus 20 to 25 days after AI had high progesterone concentrations from days 20 to $25,59.1 \%$ in the CIDR group and $50.0 \%$ in control group. The calving interval was not significantly different between the CIDR (162 \pm 50 days) and control groups (151 \pm 40 days). In conclusion, CIDR insertion 12 to 19 days after AI did not increase the detection rate of returning estrus. As a consequence, there was no effect of the CIDR treatment on the calving to conception interval.
\end{abstract}

Key words: Calving interval, CIDR, Re-synchronization, Synchronization

(J. Reprod. Dev. 56: 251-255, 2010)

$\mathbf{T}$ he first AI conception rate in dairy cows has recently been reported to be 20 to $40 \%$ [1-4]. Cows that do not conceive after first AI should be re-inseminated without delay to minimize the calving to conception interval. It is, therefore, of paramount importance that returning estrus of cows failing to conceive is detected efficiently and re-insemination is conducted after detection of estrus.

However, the returning estrus detection and re-insemination rates 20 to 25 days after AI have been reported to be about $28.0 \%$ in non-pregnant cows $[5,6]$.

The rate of detection of returning estrus would be substantially improved if returning estrus could be synchronized 20 to 25 days after AI. Recently, some studies showed that intra-vaginal insertion of a CIDR 14 to 21 days after AI increased the return rate of non-pregnant cows [7]. Other studies, however, have failed to show any improvement $[6,8]$. More recently, a study descried that addition of estradiol benzoate one day after CIDR removal increased the rate of returning to estrus [9].

We assumed that CIDR insertion during a period from 12 to 19 days after AI may better synchronize returning estrus to around 21 days after AI than CIDR insertion 14 to 21 days after AI. In most cows, luteolysis commences 17 to 18 days after estrus [10], and the dominant follicle starts to grow to maturity [11]. CIDR insertion

Received: August 5, 2009

Accepted: December 2, 2009

Published online in J-STAGE: January 27, 2010

(C)2010 by the Society for Reproduction and Development

Correspondence: T Nakao (e-mail: tnakao@yamaguchi-u.ac.jp)
12 to 19 days after AI may not interfere with that phenomenon and may still facilitate non-pregnant cows returning to estrus 20 to 25 days after AI due to supplementation of progesterone during the mid and late luteal phase.

The objectives of this study were, therefore, to examine whether CIDR insertion 12 to 19 days after AI is effective in improving the returning estrus detection rate 20 to 25 days after $\mathrm{AI}$ and shortening the interval from calving to conception.

\section{Materials and Methods}

Location, cows and housing

A total of 79 lactating Holstein Frisian cows from two dairy herds were used in this study. The experiment was conducted during the period of June 2006 to November 2007.

One herd (U farm) was located in Hokkaido, Japan, which is in northern Japan, and the other herd ( $\mathrm{T}$ farm) was in Tottori, which is in western Japan. Cows were housed in free stall barns and milked twice daily. The herds consisted of 110 and 150 Holstein cows with an annual rolling herd average of 9,500 and 12,000 kg per cow per lactation, respectively.

The cows used in this experiment were in 63 to 107 days in lactation. The mean $( \pm \mathrm{SD})$ days postpartum was $82 \pm 10.5$ days. Parity was $1.9 \pm 1.0$ on average (mean \pm SD) and ranged from one to four. The cows were clinically examined for the presence of pyometra, endometritis, urovagina and any other reproductive abnormalities before the experiment. Only cows with a BCS $>2.5$ [12] and having no reproductive disorders were used for the 


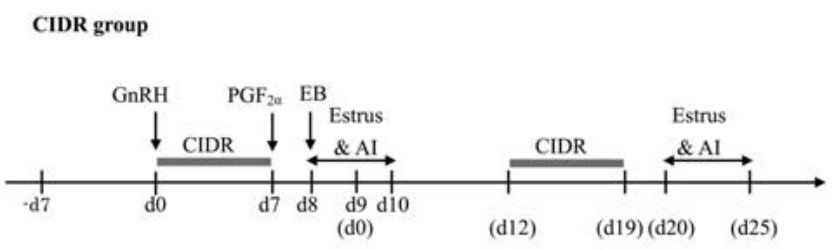

Control group

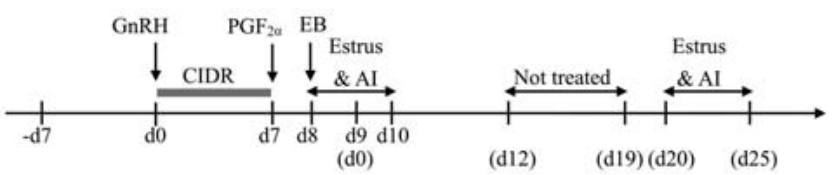

Fig. 1. Protocol for re-synchronization of returning estrus in dairy cows after synchronization of first postpartum estrus with CIDRHeatsynch. GnRH: gonadotropin-releasing hormone, $\mathrm{PGF}_{2 \alpha}$ : prostaglandin $\mathrm{F}_{2 \alpha}$, EB: estradiol-benzoate, Estrus \& AI: cows showing estrus and artificial insemination, d0: day of start of Heatsynch, (d0): day of AI.

experiment.

\section{Experimental design}

A total of 79 cows including 28 cows at $U$ farm and 51 cows at $T$ farm were inseminated artificially with frozen thawed semen after synchronization of estrus with a CIDR-Heatsynch protocol. The cows were then randomly assigned into two groups for the re-synchronization experiment. The 51 cows at $\mathrm{T}$ farm consisted of 25 cows in the CIDR group and 26 cows in the control group. Likewise, the 28 cows at $U$ farm included 12 cows in the CIDR group and 16 cows in the control group (Fig. 1).

\section{Estrus synchronization treatment}

The 79 cows at both farms received a CIDR containing $1.9 \mathrm{~g}$ of progesterone (EAZI-BREED CIDR ${ }^{\circledR}$, Livestock Improvement Association of Japan, Tokyo, Japan) in the vagina, and $100 \mu \mathrm{g}$ of GnRH analogue (Fertilin acetate, Conceral ${ }^{\circledR}$, Schering-Plough Animal Health, Tokyo, Japan) was injected intramuscularly on the day of CIDR insertion. Seven days later, the CIDR was removed, and an intramuscular injection of $500 \mu \mathrm{g} \mathrm{PGF}_{2 \alpha}$-analogue (Cloprostenol, Resipron ${ }^{\circledR}$ C, ASKA Pharmaceutical, Tokyo, Japan) was given. One mg estradiol benzoate (EB; Kawasaki Pharmaceuticals, Tokyo, Japan) was injected intramuscularly the day after $\mathrm{PGF}_{2 \alpha}$ treatment. The cows were observed for estrus within 2 days after EB injection and were inseminated artificially based on detection of estrus.

\section{Synchronization of returning estrus}

After insemination following the CIDR-Heatsynch protocol, the cows were divided randomly into two groups. A group of 37 cows were treated with a CIDR from 12 to 19 days after AI (CIDR group), while the other group of 39 cows was not treated and served as the control. The cows were observed for estrus 20 to 25 days after first AI, and those detected in estrus were re-inseminated artificially (Fig. 1).

\section{Milk sampling and progesterone ELISA}

Milk samples were collected twice weekly (Monday and Thursday) during morning milking from one week before commencement of the protocol until 25 days after AI. About $10 \mathrm{ml}$ of milk was collected in a plastic tube containing $15 \mathrm{mg}$ potassium dichromate (Wako Pure Chemical Industries, Osaka, Japan), and was kept at $4 \mathrm{C}$ until assay. Progesterone concentrations in milk were determined by an enzyme immunoassay established and validated by Isobe et al. [13]. The intra and interassay coefficients of variation in high and low progesterone pooled milk samples were $7.1 \pm 1.2$ and $14.6 \pm 0.3 \%(n=6)$ and $7.7 \pm 1.2$ and $14.6 \pm 0.3 \%(n=$ $6)$, respectively.

\section{Detection of estrus, AI and pregnancy diagnosis}

At $U$ farm, signs of estrus were observed by the farmers around $0630 \mathrm{~h}$ in the morning and at around $1800 \mathrm{~h}$ in the afternoon when the cows were moving from the barn to the milking parlor. At $\mathrm{T}$ farm, tail paint (All - Weather ${ }^{\circledR}$ Painstik ${ }^{\circledR}$ LA - CO Industries, Elk Grove, IL, USA) was used as a heat detection aid in addition to visual observation for standing and mounting. Additionally, bellowing and decrease in milk yield were also considered to be signs of estrus. Estrus detection was performed three times a day by the farmers, from 0500 to $0900 \mathrm{~h}$ in the morning, around noon and from 1600 to $1900 \mathrm{~h}$ in the afternoon. Cows were inseminated artificially by a veterinarian at $\mathrm{U}$ farm and by the farmer at $\mathrm{T}$ farm with frozen thawed semen from proven Holstein sires. Pregnancy diagnosis by transrectal palpation was conducted 35 days after AI or later by veterinarians at both farms.

\section{Definition of returning estrus based on progesterone profiles}

The effects of treatment with a CIDR for re-synchronization were evaluated based on progesterone concentrations 17 to 19 days, 20 to 24 days and 26 to 28 days after AI. Progesterone concentrations below $5.0 \mathrm{ng} / \mathrm{ml}$ were considered low, indicating absence of a CL, while progesterone concentrations $\geq 5.0 \mathrm{ng} / \mathrm{ml}$ were referred as high, indicative of luteal activity [13]. Cows showing high progesterone concentrations during 17 to 19 days after $\mathrm{AI}$ and low progesterone concentrations during 20 to 25 days after AI were considered to have returned to estrus. Other cows showing high progesterone concentrations during 17 to 19 days after AI and also high progesterone concentrations 20 to 25 days after AI were considered not to have returned to estrus 20 to 25 days after AI.

\section{Statistical analysis}

The statistical analysis was carried out using the statistical package SPSS 12.0 for Windows (SPSS, Chicago, IL, USA). Estrus detection and conception rates were compared between the CIDR and control groups during the period of 20 to 25 days after AI by a Chi-Squate test. A probability of $\mathrm{P}<0.05$ was considered statistically significant. 
Table 1. Effect of CIDR insertion 12 to 19 days after AI for re-synchronization of estrus and on reproductive performance in dairy cows

\begin{tabular}{|c|c|c|c|c|c|c|c|}
\hline \multirow[t]{2}{*}{ Item } & \multicolumn{3}{|c|}{ CIDR group } & \multicolumn{3}{|c|}{ Control group } & \multirow[t]{2}{*}{ Total } \\
\hline & $\overline{\mathrm{U} \text { farm }}$ & T farm & Total & U farm & T farm & Total & \\
\hline No. of cows synchronized for first AI & 12 & 26 & 38 & 16 & 25 & 41 & 79 \\
\hline $\begin{array}{l}\text { No. of cows with AI within } 2 \text { days } \\
\text { after synchronization (\%) }\end{array}$ & $\begin{array}{c}12 \\
(100)\end{array}$ & $\begin{array}{c}25 \\
(96.2)\end{array}$ & $\begin{array}{c}37 \\
(97.4)\end{array}$ & $\begin{array}{c}15 \\
(93.8)\end{array}$ & $\begin{array}{c}24 \\
(96.0)\end{array}$ & $\begin{array}{c}39 \\
(95.1)\end{array}$ & $\begin{array}{c}76 \\
(96.2)\end{array}$ \\
\hline No. of cows pregnant after first AI (\%) & $\begin{array}{c}5 / 12 \\
(41.7)\end{array}$ & $\begin{array}{c}9 / 25 \\
(36.0)\end{array}$ & $\begin{array}{l}14 / 37 \\
(37.8)\end{array}$ & $\begin{array}{c}8 / 15 \\
(53.3)\end{array}$ & $\begin{array}{l}10 / 24 \\
(41.7)\end{array}$ & $\begin{array}{l}18 / 39 \\
(46.2)\end{array}$ & $\begin{array}{l}32 / 76 \\
(42.1)\end{array}$ \\
\hline No. of cows not pregnant after first AI (\%) & $\begin{array}{c}7 / 12 \\
(58.3)\end{array}$ & $\begin{array}{l}16 / 26 \\
(61.5)\end{array}$ & $\begin{array}{l}23 / 38 \\
(60.5)\end{array}$ & $\begin{array}{c}8 / 16 \\
(50.0)\end{array}$ & $\begin{array}{l}13 / 25 \\
(52.0)\end{array}$ & $\begin{array}{l}21 / 41 \\
(51.2)\end{array}$ & $\begin{array}{l}44 / 79 \\
(55.7)\end{array}$ \\
\hline No. of cows returning to estrus from day 20 to day 25 & 2 & 5 & 7 & 5 & 5 & 10 & 17 \\
\hline $\begin{array}{l}\text { No. of cows resynchronized / } \\
\text { cows not pregnant after first AI (\%) }\end{array}$ & $\begin{array}{c}2 / 7 \\
(28.6)\end{array}$ & $\begin{array}{c}5 / 16 \\
(31.3)\end{array}$ & $\begin{array}{c}7 / 23 \\
(30.4)\end{array}$ & $\begin{array}{c}5 / 8 \\
(62.5)\end{array}$ & $\begin{array}{c}5 / 13 \\
(38.5)\end{array}$ & $\begin{array}{l}10 / 21 \\
(47.6)\end{array}$ & $\begin{array}{l}17 / 44 \\
(38.6)\end{array}$ \\
\hline $\begin{array}{l}\text { No. of cows that conceived at returning estrus } \\
\text { within } 6 \text { days/ cows resynchronized (\%) }\end{array}$ & $\begin{array}{c}1 / 2 \\
(50.0)\end{array}$ & $\begin{array}{c}1 / 5 \\
(20.0)\end{array}$ & $\begin{array}{c}2 / 7 \\
(28.6)\end{array}$ & $\begin{array}{c}5 / 5 \\
(100)\end{array}$ & $\begin{array}{c}2 / 5 \\
(40.0)\end{array}$ & $\begin{array}{c}7 / 10 \\
(70.0)\end{array}$ & $\begin{array}{l}9 / 17 \\
52.9\end{array}$ \\
\hline No. of cows returning to estrus from day 26 to day 40 & 1 & 3 & 4 & 0 & 5 & 5 & 9 \\
\hline No. of cows returning to estrus from day 41 to day 50 & 1 & 2 & 3 & 0 & 0 & 0 & 3 \\
\hline No. of cows that conceived within 150 days (\%) & $\begin{array}{c}3 / 7 \\
(42.9)\end{array}$ & $\begin{array}{c}5 / 16 \\
(31.3)\end{array}$ & $\begin{array}{c}8 / 23 \\
(34.8)\end{array}$ & $\begin{array}{c}4 / 8 \\
(50.0)\end{array}$ & $\begin{array}{c}5 / 13 \\
(38.5)\end{array}$ & $\begin{array}{c}9 / 21 \\
(42.9)\end{array}$ & $\begin{array}{l}17 / 44 \\
(38.6)\end{array}$ \\
\hline No. of cows that conceived within 210 days (\%) & $\begin{array}{c}5 / 7 \\
(71.4)\end{array}$ & $\begin{array}{c}9 / 16 \\
(56.3)\end{array}$ & $\begin{array}{l}14 / 23 \\
(60.9)\end{array}$ & $\begin{array}{c}6 / 8 \\
(75.0)\end{array}$ & $\begin{array}{c}9 / 13 \\
(69.2)\end{array}$ & $\begin{array}{l}15 / 21 \\
(71.4)\end{array}$ & $\begin{array}{l}29 / 44 \\
(65.9)\end{array}$ \\
\hline Calving to conception interval (Mean \pm SD; days) & $159 \pm 89$ & $169 \pm 48$ & $162 \pm 50$ & $142 \pm 42$ & $164 \pm 33$ & $151 \pm 40$ & $158 \pm 46$ \\
\hline
\end{tabular}

Table 2. Response to CIDR treatment based on progesterone profiles during re-synchronization of estrus in the CIDR-treated and control cows

\begin{tabular}{|c|c|c|c|c|c|}
\hline \multicolumn{3}{|c|}{ Milk progesterone levels } & \multirow{2}{*}{$\begin{array}{l}\text { Re-synchronization } \\
\text { of estrus }\end{array}$} & \multicolumn{2}{|c|}{ No. of cows (\%) } \\
\hline 17 to 19 days & 20 to 25 days & 26 to 28 days & & CIDR group & Control group \\
\hline \multicolumn{4}{|c|}{ No. of cows not pregnant after first AI } & 23 & 21 \\
\hline \multicolumn{4}{|l|}{ No. of cows monitored for P4 } & 22 & 18 \\
\hline $\mathrm{H}$ & $\mathrm{L}$ & $\mathrm{H}$ & Positive & $5(22.7)$ & 7 (38.9) \\
\hline $\mathrm{H}$ & $\mathrm{L}$ & $\mathrm{L}$ & Positive & $4(18.2)$ & $2(11.1)$ \\
\hline $\mathrm{H}$ & $\mathrm{H}$ & $\mathrm{L}$ & Negative & $2(9.1)$ & $1(5.6)$ \\
\hline $\mathrm{H}$ & $\mathrm{H}$ & $\mathrm{H}$ & Negative & $11(50.0)$ & 8 (44.4) \\
\hline
\end{tabular}

$\mathrm{H} \geq 5 \mathrm{ng} / \mathrm{ml}, \mathrm{L}<5 \mathrm{ng} / \mathrm{ml} .17$ to 19 days: Before removal of CIDR, 20 to 25 days: 6 days after CIDR removal, 26 to 28 days: 7 to 9 days after CIDR removal.

\section{Results}

The estrus detection rates within 2 days after the CIDR-Heatsych protocol for the first postpartum AI were $95.1 \%$ in control and 97.4\% in CIDR groups. The first AI conception rates after synchronization in the control and CIDR groups were 46.2 and $37.8 \%$, respectively. There was no difference in the non-pregnancy rates after first $\mathrm{AI}$ between $\mathrm{U}$ farm and $\mathrm{T}$ farm within both the CIDR and control groups. Likewise, the resynchronization rates of the two farms were not significantly different in both the CIDR and control groups (Table 1 ). Of the 23 cows ( 7 cows at $U$ farm and 16 cows at $\mathrm{T}$ farm) not pregnant after the first $\mathrm{AI}$ in the CIDR group, 7 cows (30.4\%) returned to estrus 20 to 25 days after AI, while $47.6 \%$ of 21 cows (7 cows at $\mathrm{U}$ farm and 14 cows at $\mathrm{T}$ farm) not conceiving after first AI in the control group returned to estrus. The conception rate after $\mathrm{AI}$ at returning estrus was $28.6 \%$ in the CIDR group, whereas it was $70.0 \%$ in the control group $(\mathrm{P}<0.05)$. The pregnancy rates within 150 days and 210 days postpartum in cows did not conceive after first AI was not significantly different between the CIDR and control groups. There was no difference in the calving to conception intervals between the CIDR and control groups (Table 1).

The returning estrus rate 20 to 25 days after AI based on the progesterone profiles was $40.9 \%$ in the CIDR group and $50.0 \%$ in the control group, and $59.1 \%$ of the non-pregnant cows in the CIDR group and $50.0 \%$ of the non-pregnant cows in the control group showed high progesterone concentrations 20 to 25 days after AI, indicating a prolonged luteal phase (Table 2).

\section{Discussion}

In this study, the pregnancy rate after first AI at estrus synchronized by CIDR-Heatsynch was $42.1 \%$ (32/76), and this is similar to the results obtained by Ovsynch in dairy cows $[14,15]$. Stevenson et al. [16] also reported that the conception rate in lactating cows after Ovsynch is $40 \%$ and that it is $50 \%$ after CIDR-Ovsynh, and 
these are equivalent to the conception rate obtained in the present study.

Insertion of a CIDR from 12 to 19 days after AI did not increase the proportion of cows that were not pregnant and returned to estrus 20 to 25 days after AI. There were no differences in reproductive performance between the two farms, as indicated by similar nonpregnancy rates after first $\mathrm{AI}$ and no difference in resynchronization rate. Only $30.4 \%$ of the non-pregnant cows that were treated with a CIDR 12 to 19 days after AI returned to estrus 20 to 25 days after AI, while $47.6 \%$ of the non-pregnant cows in the control group showed returning estrus. These results are in agreement with those reported by El-Zarkouny and Stevenson, who found that treating dairy cows with CIDR devices 13 to 20 days after AI failed to increase the overall return rate to estrus in non-pregnant cows [6]. Chebel et al. [8] also reported that insertion of a CIDR 14 and 21 days after AI in dairy cows does not improve the re-insemination rate of non-pregnant cows 20 to 25 days after AI. On the other hand, some other studies [7, 9] have shown increased return rates to estrus in cows treated with a CIDR 13 to 20 days or 14 to 21 days after AI.

The rate of detection of returning estrus after infertile breeding is influenced by the occurrence of an extended luteal phase and the incidence of embryonic mortality. If the low return rate of cows after infertile insemination was due to silent estrus, the treatment with a CIDR in the luteal phase would have been more effective. The percentage of cows not returning to estrus 20 to 25 days after infertile insemination was $69.6 \%$ in the CIDR treated group and $52.4 \%$ in the control group. The authors expected that some of the cows that had silent estrus 20 to 25 days after first AI might come into estrus 41 to 50 days after the first AI. Only 3 (13.0\%) of the 23 cows in the CIDR group showed estrus 41 to 50 days after first AI; none of the 21 control cows showed estrus 41 to 50 days after first AI. It seems that cows with silent estrus 20 to 25 days after AI still have silent estrus in the next cycle. According to the progesterone profiles, we found that almost half of the non-pregnant cows that did not show estrus during 20 to 25 days after AI had a prolonged luteal phase; more specifically, this occurred in $59.1 \%$ of the nonpregnant cows in the CIDR group and $50.0 \%$ of the non-pregnant cows in the control group (Table 2). We assumed that the extension of the luteal phase after AI is due mainly to embryonic mortality and delayed luteolysis. Alnimer et al. [7] reported that the prevalence of embryonic death during the period of day 28 to day 45 after AI was $11.9 \%$ in a group of lactating dairy cows that received a CIDR 14 to 19 days after $\mathrm{AI}$ and $17.5 \%$ in a non-treated group. Galvão et al. [17] showed that the prevalence of embryonic loss in lactating cows during the period of 27 to 41 days after AI is $15.3 \%$ to $18.1 \%$.

The incidence of prolonged luteal phase in cows was higher than $50 \%$ in this study. Hommeida et al. [18] also reported a higher milk yield in cows with a prolonged luteal phase. A tendency towards an increase in the incidence of prolonged luteal phases of the estrus cycles has been observed in dairy cows [2, 19]. It has also been reported that high milk production and the resultant increase in the metabolic clearance rate cause a low plasma concentration of estradiol [20], which delays luteolysis [21]. The increased milk production has been associated with increased liver blood flow and metabolic clearance of key steroid hormones [22]. EI-Zarkouny and Stevenson reported that more than $62.0 \%$ of the non-pregnant cows returned to estrus later than 26 days after AI in the control and CIDR groups used in their study (CIDR inserted 13 to 20 days after AI) [6]. Another study also reported that approximately $20.0 \%$ of non-pregnant beef heifers returned to estrus later than 25 days after AI in a CIDR group (CIDR inserted 13 to 20 days after $\mathrm{AI}$ ) and that approximately the rate was $22.0 \%$ in the control group [23]. Galon [24] reported that $10.9 \%$ of primiparous and $13.4 \%$ of multiparous cows had long estrus cycle lengths (25 to 36 days after AI), respectively. Bouchard and Du Tremblay showed that the interval between the first and second AIs is around 42 days and that the interval between the second and third AIs is 40 days according to lactation number in dairy cows in Quebec and Canada [25].

The pregnancy rates of cows that did not become pregnant after first insemination within 150 and 210 days postpartum of the CIDR-treated and control groups were not significantly different. These results are in agreement with the previous studies [5, 9].

In conclusion, the rate of detection of returning estrus after CIDR insertion 12 to 19 days after AI was not improved. As a consequence, there was no effect of the CIDR treatment on the calving to conception interval.

\section{Acknowledgments}

The first author is supported by a Japanese Government Scholarship for PhD study. The authors are thankful to Schering-Plough Animal Health, Tokyo, Japan, for GnRH and PGF $2 \alpha$, KawasakiMitaka Pharmaceuticals Co., Ltd, Tokyo, Japan, for estradiol benzoate and the Livestock Improvement Association of Japan, Tokyo, Japan, for the CIDR devices. We would like to offer our sincere thanks to the herd owners involved in this study for their cooperation.

\section{References}

1. Lucy MC. Reproductive loss in high-producing dairy cattle: where will it end? J Dairy Sci 2001; 84: 1277-1293.

2. Royal MD, Darwash AO, Flint APF, Webb R, Woolliams JA, Lamming GE. Declining fertility in dairy cattle: changes in traditional and endocrine parameters of fertility. Anim Sci 2000; 70: 487-501.

3. Washburn SP, Silvia WJ, Brown CH, McDaniel BT, McAllister AJ. Trends in reproductive performance in southeastern Holstein and Jersey DHI herds. J Dairy Sci 2002; 85: 244-251.

4. Pursley JR, Wiltbank MC, Stevenson JS, Ottobre JS, Garverick HA, Anderson LL Pregnancy rates per artificial insemination for cows and heifers inseminated at a synchronized ovulation or synchronized estrus. J Dairy Sci 1997; 80: 295-300.

5. Chenault JR, Boucher JF, Dame KJ, Meyer JA, Wood-Follis SL. Intravaginal progesterone insert to synchronize return to estrus of previously inseminated dairy cows. J Dairy Sci 2003; 86: 2039-2049.

6. El-Zarkouny SZ, Stevenson JS. Resynchronizing estrus with progesterone or progesterone plus estrogen in cows of unknown pregnancy status. J Dairy Sci 2004; 87: 33063321.

7. Alnimer MA, Lubbadeh WF. Effect of progesterone (P4) intravaginal device (CIDR) to reduce embryonic loss and to synchronize return to oestrus of previously timed inseminated lactating dairy cows. Anim Reprod Sci 2008; 107: 36-47.

8. Chebel RC, Santos JE, Cerri RL, Rutigliano HM, Bruno RG. Reproduction in dairy cows following progesterone insert presynchronization and resynchronization protocols. J Dairy Sci 2006; 89: 4205-4219.

9. Stevenson JS, Johnson SK, Medina-Britos MA, Richardson-Adams AM, Lamb GC 
Resynchronization of estrus in cattle of unknown pregnancy status using estrogen, progesterone, or both. J Anim Sci 2003; 81: 1681-1692.

10. Shirasuna K, Matsui M, Shimizui T, Miyamoto A. Local mechanisms for luteolysis in the cow: Novel roles of vasoactive substances in the luteolytic cascade within the corpus luteum. Anim Sci J 2007; 78: 460-466.

11. Lucy MC, Savio JD, Badinga L, De La Sota RL, Thatcher WW. Factors that affect ovarian follicular dynamics in cattle. J Anim Sci 1992; 70: 3615-3626.

12. Ferguson JD, Galligan DT, Thomsen N. Principal descriptors of body condition score in Holstein cows. I Dairy Sci 1994; 77: 2695-2703.

13. Isobe N, Yoshimura T, Yoshida C, Nakao T. Incidence of silent ovulation in dairy cows during post partum period. Dtsch Tierärztl Wochenschr 2004; 111: 35-38.

14. Wittke M, Drillich M, Tenhagen BA, Heuwieser W. Comparison of ovulation synchronization (Ovsynch) with the selective induction of oestrus using PGF2alpha after rectal palpation in a dairy herd. Dtsch Tierarztl Wochenschr 2005; 112: 368-374.

15. Peters MW, Pursley JR. Fertility of lactating dairy cows treated with Ovsynch after presynchronization injections of PGF2 $\alpha$ and GnRH. J Dairy Sci 2002; 85: 2403-2406.

16. Stevenson JS, Pursley JR, Garverick HA, Fricke PM, Kesler DJ, Ottobre JS, Wiltbank MC. Treatment of cycling and noncycling lactating dairy cows with progesterone during Ovsynch. J Dairy Sci 2006; 89: 2567-2578.

17. Galvão KN, Santos JP, Juchem SO, Cerri RL, Coscioni AC, Villaseñor M. Effect of addition of a progesterone intravaginal insert to a timed insemination protocol using estradiol cypionate on ovulation rate, pregnancy rate, and late embryonic loss in lac- tating dairy cows. J Anim Sci 2004; 82: 3508-3517.

18. Hommeida A, Nakao T, Kubota H. Onset and duration of luteal activity postpartum and their effect on first insemination conception rate in lactating dairy cows. J Vet Med Sci 2005; 67: 1031-1035.

19. Shrestha HK, Nakao T, Suzuki T, Higaki T, Akia M. Effect of abnormal ovarian cycles during pre-service period postpartum on subsequent reproductive performance of high-producing Holstein cows. Theriogenology 2003; 61: 1559-1571.

20. Rocher JF. The effect of nutritional management of the diary cow on reproductive efficiency. Anim Reprod Sci 2006; 96: 282-296.

21. Wiltbank M, Lopez H, Sartori R, Sangsritavong S, Gümen A. Changes in reproductive physiology of lactating dairy cows due to elevated steroid metabolism. Theriogenology 2006; 65: 17-29.

22. Sangsritavong S, Combs DK, Sartori R, Armentano LE, Wiltbank MC. High feed intake increases liver blood flow and metabolism of progesterone and estradiol-17 $\beta$ in dairy cattle. J Dairy Sci 2002; 85: 2831-2842.

23. Colazo MG, Kastelic JP, Mainar-Jaime RC, Gavaga QA, Whittaker PR, Small JA, Martinez MF, Wilde RE, Veira DM, Mapletoft RJ. Resynchronization of previously timed-inseminated beef heifers with progestins. Theriogenology 2006; 65: 557-572.

24. Galon N. Factors affecting reproductive performance in Israeli dairy herds. In: Proceeding of $25^{\text {th }}$ World Buiatrics Congress; 2008; 28-36.

25. Bouchard E, Du Tremblay D. Dairy herd production and reproduction in Quebec and Canada. In: Proceeding of $25^{\text {th }}$ World Buiatrics Congress; 2008; 60-66. 